\title{
David Oliver: Moral distress in hospital doctors
}

\author{
David Oliver consultant in geriatrics and acute general medicine
}

Berkshire

The concept of "moral distress" in nurses was described by Andrew Jameton in $1984 .{ }^{1}$ He has defined it as occurring when one knows the right thing to do for a patient but institutional constraints make it impossible to pursue that course of action. ${ }^{23}$ The medical literature has plenty on physician burnout, poor working conditions, and their effects on doctors' wellbeing. ${ }^{45}$ We haven't tended to discuss moral distress as much as nurses do, although we clearly experience it too.

The Point of Care Foundation ${ }^{6}$ has worked with over 180 organisations throughout the NHS, specifically supporting clinical teams. The foundation's director, Jocelyn Cornwell, told me, "I have learned that moral distress is widely felt by doctors and nurses but also porters, ward clerks, paramedics - and by managers, when they are aware of the pressure and unable to mitigate it. In short, everyone who works close to or directly with patients is at risk."

Morale, engagement, and wellbeing in clinical staff affect quality of care, sickness absence, and retention-described especially clearly by Michael West and Jeremy Dawson for the King's Fund. ${ }^{78}$ The 2018 British Social Attitudes survey of 3000 citizens showed a sharp drop in public satisfaction with the NHS. Short staffing, underfunding, worsening access, and waiting times were the biggest issues raised. ${ }^{9}$ The 2017 annual NHS staff survey showed deteriorating morale and engagement, with work pressures and staffing gaps cited. ${ }^{10}$ And NHS Improvement's recent workforce report showed that one in 11 NHS clinical posts is unfilled, including $8 \%$ vacancies for doctors-higher by far in some pressurised specialties or regions. ${ }^{11}$

In recent months we've had reports of short staffing, lack of capacity, and unmanageable demand putting care quality and patients at risk, such as in general practice, emergency medicine, psychiatry, paediatrics, and intensive care. ${ }^{12-16}$ This, in turn, leaves doctors feeling unable to give the standard of care they were trained to or that patients want. Rushed, missed, or risky care will inevitably lead to fear and feelings of loss of control among conscientious medics.
Resilience should be for the difficult emotional burden of caring, responsibility, and carrying risk-not for unacceptable, dangerous working conditions

Interest is growing in resilience training for NHS staff. But I'm not convinced that there is good evidence for its benefit. And, surely, resilience should be for the difficult emotional burden of caring, responsibility, and carrying risk-not for unacceptable and potentially dangerous working conditions.

The Point of Care Foundation has had success in introducing Schwartz rounds, ${ }^{17}$ now formally evaluated in a longitudinal National Institute for Health Research study with positive results for staff morale. ${ }^{18}$ During these rounds staff can share the difficult emotional effects of providing care while retaining compassion in a facilitated safe space. ${ }^{19}$

Jocelyn Cornwell cited as key factors in improving working conditions: shared values and mutual support in teams; managers being willing to talk openly and honestly about pressure (and finding ways to mitigate it); and low tolerance for poor behaviour. She also emphasised the behaviour of senior clinicians and managers-in role modelling, valuing, and engaging clinical teams - as being crucial to frontline staff.

Maybe the starting point in handling moral distress in doctors and other health practitioners is to speak its name rather than play down its existence.

Competing interests: See bmj.com/about-bmj/freelance-contributors/david-oliver. Provenance and peer review: Commissioned; not externally peer reviewed.

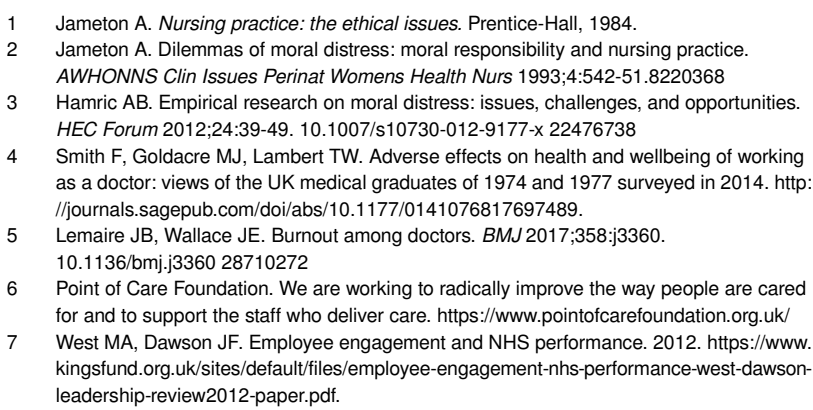


8 West M. It's not about the money: staff engagement comes first. 7 March 2018. https:// www.kingsfund.org.uk/blog/2018/03/staff-engagement-comes-first.

9 Robertson R, Appleby J, Evans H. Public satisfaction with the NHS and social care in 2017: results and trends from the British Social Attitudes survey. 28 Feb 2018. https:// www.nuffieldtrust.org.uk/research/public-satisfaction-with-the-nhs-and-social-care-in-2017.

10 NHS Survey Coordination Centre. 2017 results. www.nhsstaffsurveys.com/Page/1064/ Latest-Results/2017-Results/.

11 Matthews-King A. More than 100000 NHS posts unfilled, reveal "grim" official figures. Independent 21 Feb 2018. https://www.independent.co.uk/news/health/nhs-posts-staffingrecruitment-official-figures-healthcare-hospitals-a8221961.html.

12 Baird B. Is general practice in crisis? Big election questions. 1 June 2017. https://www. kingsfund.org.uk/publications/articles/big-election-questions-gp-crisis.

13 Kentish B. Number of mental health patients treated hundreds of miles from home hits new high. Independent 5 March 2017. https://www.independent.co.uk/news/mental-healthpatients-out-of-area-placements-theresa-may-psychosis-anorexia-schizophrenia-a7611571. html.

14 Ault R. NHS patients "dying prematurely" in corridors, doctors warn. Stoke Sentinel 13 Jan 2018. https://www.stokesentinel.co.uk/news/stoke-on-trent-news/nhs-patients-dyingprematurely-corridors-1052870.
15 Royal College of Paediatrics and Child Health. Rota compliance and vacancies. July 2017. https://www.rcpch.ac.uk/improving-child-health/better-nhs-children/workforceplanning/rota-compliance-and-vacancies/rota-com.

6 Campbell D. NHS intensive care "at its limits" because of staff shortages. Guardian 29 Jan 2017. https://www.theguardian.com/society/2017/jan/29/nhs-intensive-care-at-itslimits-because-of-staff-shortages.

17 Point of Care Foundation. Schwartz rounds. https://www.pointofcarefoundation.org.uk/ our-work/schwartz-rounds/.

18 National Institute for Health Research. A longitudinal national evaluation of Schwartz Centre Rounds: an intervention to enhance compassion in relationships between staff and patients through providing support for staff and promoting their wellbeing. Sept 2014 https://www.journalslibrary.nihr.ac.uk/programmes/hsdr/130749/\#/.

19 Robert G, Philippou J, Leamy M, etal . Exploring the adoption of Schwartz Center Rounds as an organisational innovation to improve staff well-being in England, 2009-2015. BMJ Open 2017;7:e014326. http://bmjopen.bmj.com/content/7/1/e014326. 10.1136/bmjopen-2016-014326 28057662

Published by the BMJ Publishing Group Limited. For permission to use (where not already granted under a licence) please go to http://group.bmj.com/group/rights-licensing/ permissions 